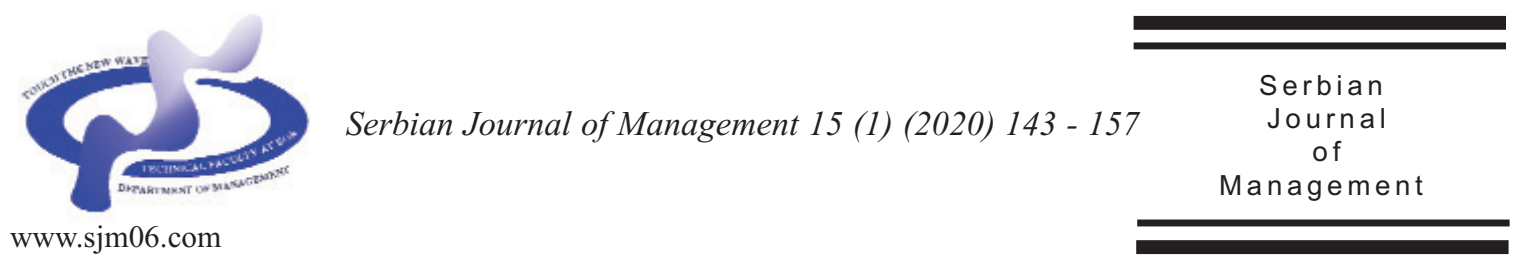

\title{
ANALYSIS OF THE RELATIONSHIP BETWEEN ORGANIZATIONAL COMMITMENT AND COUNTER PRODUCTIVE WORK BEHAVIOUR ON ACADEMICIANS
}

\author{
Canan Baysal $^{\mathbf{a}^{*}}$, Fulya Mısırdalı Yangil ${ }^{\mathrm{b}}$ and Şerafettin Sevimb \\ $a_{\text {Kocaeli University, Institute of Social Sciences, }}$ \\ Umuttepe Campus 41380, Izmit/Kocaeli, Turkey

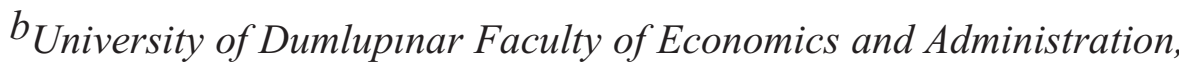 \\ Evliya Çelebi Kampüsü Tavşanlı Yolu 10. Km, Kütahya,Turkey
}

(Received 03 August 2018; accepted 02 March 2020)

\begin{abstract}
This study investigates the relationship between counter productive work behavior and organizational commitment which is one of the problems that organizations frequently face with in recent years. The relationship between affective commitment, normative commitment and continuance commitment from organizational commitment dimensions and abuse, production deviance, sabotage, theft and withdrawal from counter productive work behavior are examined one by one. The study has been conducted with the participation of 219 academic staff working at Dumlupinar University. In the study, a correlation analysis is performed to determine the relationship between the variables. Furthermore, Kruskal-Wallis H and Mann-Whitney U tests are conducted to determine their association with demographic variables. As a result of the analyses this study detects that affective commitment and normative commitment dimensions have negative direction and significant relationship with the withdrawal and abuse dimensions. Additionally, the negative direction and significant relationships are found between continuance commitment and withdrawal, abuse, theft dimension.
\end{abstract}

Keywords: academic staff, counter productive work behavior, organizational commitment

\section{INTRODUCTION}

Rapidly developing technological advancements and conditions of intensive competition make surviving difficult for organizations. Besides the effectively use the ever-changing and ever-growing financial and technological capitals, effectively and

This study is derived from a master's thesis called "Analysis of The Relationship Between Organizational Commitment and Counter Productive Work Behaviour on Academicians" prepared to Institute of Social Sciences at Dumlupınar University.

* Corresponding author: canan.baysal@kocaeli.edu.tr

DOI: $10.5937 /$ sjm15-18502 
productively use the human capital has a critical importance in surviving of an organization. Being focused on 'human capital' by the organizations in value creation results from this importance mentioned. The commitment of employees who are accepted as the value creator (intellectual) capital of the organizations has importance in continuing organizations' existence as the long-termed properties.

Organizational commitment concept that is one of the most significant issues of organizational behavior and organizational psychology is a form of understanding. Moreover, this concept confronts as an essential concept in organizations where the human capital is a necessity. Being positively and negatively reflected the behavior and attitudes of organization members toward organizations is called as the organizational commitment. Organizational commitment reflects the integration degree of workers to the organization. When viewed from this aspect, organizational commitment is a faith for the purpose and values adopted by the organization; displaying wishful behaviors to make beneficial things to the organization; a strong desire to maintain the organization membership (Balay, 2014).

It is seen that the workers display behaviors beyond the negative role towards workmates in superior-subordinate relationships as the result of the nature of business and personal characteristics. These behaviors of workers against the organization are called the counterproductive work behaviors in literature. With reference to the observations, the interest towards the behaviors beyond the negative role has increased in literature as from the 1990s. Some of the investigators accept the reason for this circumstance as the result arising from the liberalization tendency that has emerged in industry relationships for the last 20-30 years period (Çetin \& F1kırkoca, 2010). Counterproductive work behavior that mean being intentionally damaged the organization or organization members by the workers have analyzed in psychology, sociology, economics and many other fields (Marcus \& Schuler, 2004). Counterproductive work behaviors arise from the individual competition of workers or the competition between groups. Such behaviors do not only damage the organizational goals but also negatively affect the daily life and business lives of the workers (Mount et al., 2006).

The purpose of this study was to reveal the relationship between the organizational commitment that means showing a volunteer and outstanding effort for the benefit of the organization and the counterproductive work behaviors that mean ignoring the organization's benefit or malicious pattern of behaviors of the workers toward the organization.

\section{LITERATURE REVIEW AND THEORETICAL FRAMEWORK}

\subsection{Counter-Productive Behavior \\ Work}

Several investigators who studied on counterproductive work behaviors define this concept in different manners. According to the definition of Sackett (2002), counter productive work behaviors are the attitudes which contrary to the legitimate interests of members of the organization; these attitudes are intentionally displayed to damage the organization. Robinson and Bennet (1995) defined the concept as the aberrant behaviors that are the voluntary attitudes toward 
disquiet the organization members, disregard the organization rules or actualize both of them. With reference to the definition of Spector and Fox (2005), counterproductive work behaviors are the intentional and voluntary behaviors to damage both the organization, managers, colleagues and the customers (cited. Polatçı et al., 2014).

In the light of the definitions above, the common ground of counterproductive work behaviors is the negative attitudes that are intentionally displayed to damage the organization and organization members (Hafidz, 2012). Even though, there are used different concepts to express the negative behaviors arise in organizations, all the behaviors that aim to damage the organization by the ways like theft, sabotage, interpersonal aggressiveness, slowdown, waste of time and resources, rumor mongering are evaluated within the scope of counterproductive work behaviors (Penney $\&$ Spector, 2002).

There is not a consensus on classifying the counterproductive work behaviors in the literature. Hollinger and Clark (1983) who have the first comprehensive study on the counterproductive work behaviors analyzed this concept under two dimensions. The first dimension is the aberrant behaviors against the property; the second one the aberrant behaviors against the production. However, Bennett and Robinson (2000) classified the counterproductive work behaviors as two different manners; interindividual and organizational. Spector et al., (2006) evaluate the counterproductive work behaviors within 5 dimensions; abuse, production deviance, sabotage, theft, and withdrawal. Abuse dimension contains the behaviors such as threatening, making offensive comments, frightening, etc. Production deviance dimension means the breach of duty and responsibilities, knowingly performing the duties wrong, underperforming, slowdown, violating the procedures. Sabotage dimension is composed of the behaviors toward damage the property and resources of the organization by having a hostile feeling. Theft dimension means being stolen the things of organization or organization members by the workers based on the facts of economic need, job dissatisfaction or injustice. Withdrawal dimension includes the behaviors such as use the break times longer, absenteeism, coming to the job late or leaving from the job earlier.

\subsection{Organizational Commitment}

Organizational commitment concept is a concept that has been discussed in various disciplines such as sociology, psychology, and philosophy. The main cause of this situation is that the concept mentioned organizationally affects the factors such as labor turnover, absenteeism, job performance and job satisfaction. There are several definitions of the organizational commitment in the literature. To gain a clear understanding on those definitions has importance in terms of both individual and organizations.

Etzioni pointed out that the organizations' powers and provinces that are used to direct the behaviors of the organization members are associated with the members' commitments to the organization (Lunenburg, 2012). O'Reilly and Chatman defined the concept as sensationally attaching to the organization (Anttila, 2014). Becker described the organizational commitment as being associated the consistent behaviors with a number of benefits by making side bets (Becker, 1960). 
According to Salancik, the organizational commitment is based on the compliance relationship between workers' behaviors and attitudes (Gül, 2003).

Organizational commitment concept is defined as the psychological commitment including performing the duties, addressing oneself to the job, accepting the organizational values (Ulutürk, 2016).

Allen and Meyer (1991) analyzed the organizational commitment under three titles. One of those titles is the affective commitment. Integration degree of workers with the organization, active participation to the organizational activities and also the emotional bond between the worker and organization mean the affective commitment. The workers who have a strong affective commitment are in the tendency to remain a part of the organization and sustain the organization membership (Noordin et al., 2011). Another title that is the continuance commitment that means perceived cost signifies that being aware of the costs in case of leaving from the organization membership (McMahon, 2007). The third title is the normative commitment that reflects the feelings of sustaining the organization membership (Allen \& Meyer, 1991). Following factors provide workers to perceive the organizational commitment as a virtue; past experiences, habits, customary rules, social and cultural values of the workers, to be working in the same organization for a long time; being appreciated by earning the organization's trust. Within this scope, the workers continue their organization memberships by accepting this type of commitment as a virtuous behavior (Kaya \& Selçuk, 2007).

\subsection{The Relationship Between Organizational Commitment and Counter-Productive Work Behavior}

According to Demirel (2009), there is seen a decrease in productivity-reducing behaviors of workers in case of providing factors cause increasing the organizational commitment. It is observed when analyzing the relationship between organizational commitment and counterproductive work behavior that the processors that cause to the organizational commitment directly or indirectly affect in displaying counterproductive work behaviors. Tüfekçi et al., (2016) determined significant relationships between organizational commitment and the sub-dimensions of counterproductive work behaviors. Doğruöz and Özdemir (2018) conducted a study on the relationship between counterproductive work behavior in educational organizations and organizational commitment. They emphasized at the end of the research that the counterproductive work behaviors are a significant predictor of the organizational commitment.

Demirel (2009) argued that the perceptions like management style, organizational justice, ethical climate, organizational trust, organizational citizenship behavior, organizational support cause to the counterproductive work behaviors. With reference to Kanten and Ülker (2014), democratic management style negatively affects the counterproductive work behaviors of the workers. Gerçek (2017) performed a survey to research the effect of the ethical climate and organizational trust on the counterproductive work behaviors. He pointed out that the ethical climate and the organizational trust negatively affect the counterproductive work behaviors. 
Polatçı and Özçalık (2015) analyzed whether the organizational justice has an effect on displaying counterproductive work behavior. According to their research finding, even though the feeling of injustice that is felt during the distribution of resources in organizations does not direct workers to display counter productive work behaviors, the workers may still display such behaviors because of having negative feelings as the result of this distribution. Polatç1 et al., (2014) found a reversed relationship between organizational citizenship behavior and the counterproductive work behavior. Akbaş Tuna and Boylu (2016) conducted a study to reveal the connection between perceived organizational support and the counterproductive work behavior. They emphasized at the end of the study that the organizational support has a negative effect on theft, withdrawal and abuse dimensions. Doğan and Deniz (2017) found partly and directly related relationships between counterproductive behaviors and the leadership styles. They revealed that the organizational culture plays a regulatory role between the variables.

Within this framework, the main goal of the research was to reveal the relationship between organizational commitment levels of the academicians and displaying frequency of counterproductive work behaviors. The hypotheses that are developed based on this goal are as follows:

H1 :There is a significant relationship between organizational commitment subdimensions of the academicians and the counterproductive work behavior subdimensions.

H2 : Affective commitment, continuance commitment and normative commitment levels from the organizational commitment sub-dimensions of the academicians vary by their demographic attributes.

H3: Displaying frequencies of abuse, production deviation, sabotage, theft and withdrawal behaviors from counterproductive work behavior subdimensions of academicians vary by their demographic attributes.

\section{RESEARCH METHOD}

This study was analyzed by a quantitative research approach as well as conducted in relational screening model.

\subsection{Population and Sample}

The population was composed of 467 academic staff work in the central campus of Dumlupınar University in Kütahya Province. The convenience sampling method that is composed of the accessible participants was used in this research. Data of 219 participants were analyzed.

About the demographic information of participants, $33.8 \%$ of them were females, $66.2 \%$ of them were the males. $68.0 \%$ of them were married; $32.0 \%$ of them were single. $47.9 \%$ of them have worked in the same organization for 10 years and above; $12.8 \%$ of them have worked in the same organization between 6 and 9 years; $35.6 \%$ of them have worked in the same organization between 1 and 5 years; only 8 of them have worked in the same organization for a year and less. About the total working hours during the career, $24.2 \%$ of them have worked for 5 years and less; $55.7 \%$ of them have worked between 6 and 19 years; 20.1\% of them have worked for 20 years and above. About the girdle distribution, baby boomer generation has $9.1 \%$ share; $\mathrm{X}$ generation has 
$42.5 \%$ share; Y generation has $48.4 \%$ share. $8.7 \%$ of participants were the professors; $13.2 \%$ of them are docents; $29.2 \%$ of them are assistant professors; $5.0 \%$ of them are teaching assistants; $43.8 \%$ of them are research assistants. $10.0 \%$ of participants work in faculty of education; $18.3 \%$ of them work in the faculty of science and letters; $7.3 \%$ work in faculty of fine; $33.3 \%$ of them work in faculty of economics and administrative sciences; $8.2 \%$ of them work in faculty of theology; $22.8 \%$ of them work in engineering faculty. While the ratio of workers in administrative function was $26.5 \%$, the workers who are not in administrative function was $73.5 \%$.

\subsection{Data Measurement}

Scales were utilized in collecting the data. The scale form consists of three parts. In the first part, demographic information form with 8 questions was applied. Organizational Commitment Questionnaire (OCQ) with 18 items that were developed by Allen Meyer (1991) was used in the second part of the scale form to measure the organizational commitment level. In the third part, Overview of the Counterproductive Work Behavior Checklist (CWB-C) with 33 items that were developed by Spector and Fox (2005) was utilized to measure the counterproductive work behaviors. It is seen when looking at the reliability analysis results of organizational commitment that the Cronbach Alpha coefficient for affective commitment is quite reliable as .861; for normative commitment is quite reliable as .698; for continuance commitment is quite reliable as .768; for organizational commitment is highly reliable as .844 .

\section{FINDINGS}

Correlation analysis was utilized to determine the relationship between the organizational commitment and counterproductive work behavior. Since the data did not show normal distribution, Table 1 shows the results of the analysis that was applied by using the Spearman coefficient.

As is seen in the table, there is a negative and statistically significant relationship at a medium-low level between abuse and withdrawal dimensions. This same significant relationship can be seen between affective commitment and normative commitment as the result of the correlation analysis performed between the variables. A

Table 1. Findings Relating to Correlation Analysis Between Organizational Commitment Sub-dimensions and Counter-Productive Work Behavior Sub-dimensions

\begin{tabular}{lrrrrrr}
\hline & & Abuse & $\begin{array}{r}\text { Production } \\
\text { Deviation }\end{array}$ & Sabotage & Theft & Withdrawal \\
\hline Affective commitment & $\mathbf{r}$ & $\mathbf{- . 3 9 6 * *}$ & -.059 & -.044 & .085 & $\mathbf{- . 3 4 4 * *}$ \\
& $\mathbf{p}$ & .000 & .383 & .516 & .208 & .000 \\
& $\mathbf{n}$ & 219 & 219 & 219 & 219 & 219 \\
Continuance commitment & $\mathbf{r}$ & $\mathbf{- . 2 6 6 * *}$ & -.097 & -.112 & $\mathbf{- . 1 7 8 * *}$ & $\mathbf{- . 1 7 4 * *}$ \\
& $\mathbf{p}$ & .000 & .151 & .099 & .008 & .010 \\
Normative commitment & $\mathbf{n}$ & 219 & 219 & 219 & 219 & 219 \\
& $\mathbf{r}$ & $\mathbf{- . 2 8 9 * *}$ & -.055 & -.112 & -.085 & $\mathbf{- 2 0 3 * *}$ \\
& $\mathbf{p}$ & .000 & .414 & .098 & .211 & .003 \\
& $\mathbf{n}$ & 219 & 219 & 219 & 219 & 219 \\
\hline
\end{tabular}


statistically negative relationship at a low level was determined between continuance commitment, abuse, theft and withdrawal dimensions. With reference to the findings above, $\mathrm{H}_{1}$ hypothesis was partly accepted.

Mann-Whitney $\mathrm{U}$ and Krusal-Wallis $\mathrm{H}$ tests that are applied for data that do not show normal distribution were conducted to analyze whether demographic attributes create a difference in displaying frequencies of organizational commitment subdimensions and counterproductive work behavior sub-dimensions. In Table 2, the Kruskal-Wallis $\mathrm{H}$ test was conducted to determine whether the frequency of the participants exhibiting counter productivite work behavior varies according to the faculty variable.

In Table 3, the Mann Whitney-U test was conducted to determine whether the organizational commitment levels of the participants differ according to the gender variable. While in Table 4, Mann Whitney-U test was conducted to determine whether the frequency of abuse behavior, which is one of the sub-dimensions of counter productivite work behavior, varies according to the administrative task variable

As is seen in the analyses, there is a statistically significant difference between faculty variable and displaying counterproductive work behavior. Since the p-value is not bigger than $0,05(\boldsymbol{p}=\mathbf{0 , 0 4 7})$, there is a significant difference between the averages of at least two of the groups $\left(\mathbf{X}^{\mathbf{2}}=\mathbf{1 1}, \mathbf{2 2 1}, \boldsymbol{p}<\mathbf{0 , 0 5}\right)$. It is determined at the end of multiple comparisons, there is a difference between faculty of education and faculty of science and letters.

There is a statistically significant difference between continuance commitment and gender variable $(\mathbf{U}=\mathbf{4 1 0 4 . 5 0 0}, \boldsymbol{p}<\mathbf{0 . 0 5})$. It is pointed out that the continuance commitment of female participants is higher

Table 2. Kruskal-Wallis H Test Results of Displaying Frequencies of Counter Productive Work Behavior based on Faculty Variable

\begin{tabular}{lcccc}
\hline Groups & N & Rank average & $\mathbf{X}^{\mathbf{2}}$ & $\mathbf{p}$ \\
\hline Faculty of Education & 22 & 142.75 & 11.221 & $\mathbf{0 . 0 4 7}$ \\
Faculty of Science and Letters & 40 & 91.81 & & \\
\hline
\end{tabular}

Table 3. Mann-Whitney U Test Results of Organizational Commitment Levels of Participants Based on Gender Variable

\begin{tabular}{lcccc}
\hline Groups & N & Rank average & $\mathbf{U}$ & $\mathbf{p}$ \\
\hline Female & 74 & 127.03 & 4104.500 & $\mathbf{. 0 0 4}$ \\
Male & 145 & 101.31 & & \\
\hline
\end{tabular}

Table 4. Mann-Whitney U Test Results of Displaying Frequencies of Abuse Behavior based on Administrative Function

\begin{tabular}{lcccc}
\hline Groups & N & Rank average & $\mathbf{U}$ & $\mathbf{p}$ \\
\hline Administrative (available) & 58 & 127.25 & 3668.500 & $\mathbf{. 0 0 9}$ \\
Function (none available) & 161 & 103.79 & & \\
\hline
\end{tabular}


in comparison with the continuance commitment of male participants.

There was observed a statistically significant difference between displaying the frequency of abuse behaviors based on administrative function $\quad(\mathbf{U}=\mathbf{3 6 6 8 . 5 0 0}$, $\boldsymbol{p}<\mathbf{0 . 0 5}$ ). Analysis results show that the participants who are in administrative function display abuse behaviors more frequent.

In Table 5, Mann-Whitney $U$ test was conducted to determine whether the level of affective commitment, which is one of the organizational commitment sub-dimensions, varies according to the variable of career advancement (seniority). In Table 6, Kruskal-Wallis $\mathrm{H}$ test was conducted to determine whether the level of emotional commitment, which is one of the organizational commitment sub-dimensions, differs according to the faculty variable. In Table 7, the Kruskal-Wallis $H$ test was conducted to determine whether the frequency of abuse behavior, which is one of the sub-dimensions of counter productive work behavior, varies according to the career progression (seniority) variable.

There was observed a statistically significant difference between affective commitment and total working period in a career (seniority) $(\mathbf{U}=\mathbf{9 . 6 6 1}, \boldsymbol{p}<\mathbf{0 . 0 5})$. It was found that the significant difference is between the participants who have worked for 20 years and above and the group who have worked between 6-19 years.

There was found a statistically significant difference between affective commitment level of participants and the faculty variable $\left(X^{2}=\mathbf{1 2 . 3 4 5}, p<\mathbf{0 . 0 5}\right)$. It was found that the significant difference is between faculty of education and faculty of science and letters.

There can be seen a statistically significant difference between displaying frequency of abuse behaviors and total

Table 5. Mann-Whitney U Test Results of Affective Commitment Levels of Participants based on Total Working Period in Career

\begin{tabular}{lcccc}
\hline Groups & N & Rank average & $\mathbf{U}$ & $\mathbf{p}$ \\
\hline Between 6-19 years & 122 & 98.41 & 9.661 & $\mathbf{. 0 0 8}$ \\
20 years and above & 44 & 129.02 & & \\
\hline
\end{tabular}

Table 6. Kruskal-Wallis H Test Results of Affective Commitment Levels of Participants Based on Faculty Variable

\begin{tabular}{lcccc}
\hline Groups & N & Rank average & $\mathbf{X}^{\mathbf{2}}$ & $\mathbf{p}$ \\
\hline Faculty of Education & 22 & 69.80 & 12.345 & $\mathbf{. 0 3 0}$ \\
Fac. Sci. and Let. & 40 & 122.43 & & \\
\hline
\end{tabular}

Table 7. Kruskal-Wallis H Test Results of Displaying Frequency of Abuse Behaviors of Participants based on Total Working Period (Seniority)

\begin{tabular}{lcccc}
\hline Groups & $\mathbf{N}$ & Rank average & $\mathbf{X}^{\mathbf{2}}$ & $\mathbf{p}$ \\
\hline Between 6-19 years & 122 & 122.27 & 14.004 & $\mathbf{. 0 0 1}$ \\
20 years and above & 44 & 85.38 & & \\
\hline
\end{tabular}


working period in career variable. In this circumstance, since the $\mathrm{p}$-value is not bigger than $0.05(\boldsymbol{p}=\mathbf{0 . 0 0 1})$, there is a significant difference between the averages of at least

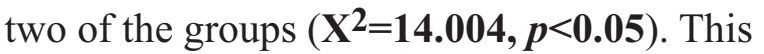
difference is between the group whose total working period is 20 years and above and the group working period is between 6-19 years.

In Table 8 , Kruskal-Wallis $\mathrm{H}$ test was conducted to determine whether the frequency of abuse behavior, which is one of the sub-dimensions of counter productive work behavior, varies according to the faculty variable. In Table 9, the KruskalWallis $\mathrm{H}$ test was conducted to determine whether the frequency of production deviance which is one of the sub-dimensions of counter productive work behavior, varies according to the variable of career advancement (seniority).

There was found a statistically significant difference between faculty variable and displaying frequency of abuse behaviors. In this circumstance, since the $\mathrm{p}$-value is not bigger than $0.05 \quad(\boldsymbol{p}=\mathbf{0 . 0 0 3})$, there is a significant difference between the averages of at least two of the groups $\left(\mathbf{X}^{\mathbf{2}}=\mathbf{1 7 . 8 3 1}\right.$ $\boldsymbol{p}<\mathbf{0 . 0 5}$ ). With reference to the multiple comparisons, this difference is between faculty of education, faculty of science and letters and faculty of fine arts. This same difference can also be seen between faculty of education, engineering faculty and faculty of education.
There was found a statistically significant difference between displaying the frequency of production deviance behaviors of participants and total working period in the same institution variable $\left(\mathrm{X}^{\mathbf{2}}=\mathbf{1 1 . 5 2 2}\right.$, $\boldsymbol{p}<\mathbf{0 . 0 5}$ ). In this circumstance, since the $\mathrm{p}$ value $(\boldsymbol{p}=\mathbf{0 . 0 0 9})$ is not bigger than 0.05 , there is a significant difference between the averages of at least two of the groups. With reference to the multiple comparisons, this difference is between the group who worked in the same group between 6-9 years and the group who worked in the same institution for 10 years and above.

In Table 10, Kruskal-Wallis $\mathrm{H}$ test was conducted to determine whether the frequency of sabotage behavior, which is one of the sub-dimensions of counter productive work behavior, varies according to the faculty variable. According to the table 10, there is a statistically significant difference between displaying frequency of sabotage behaviors and the faculty variable $\left(\mathbf{X}^{\mathbf{2}}=\mathbf{1 1 . 4 1 2}, \boldsymbol{p}<\mathbf{0 . 0 5}\right)$. In this circumstance, since the $p$-value is not bigger than 0.05 $(\boldsymbol{p}=\mathbf{0 . 0 4 4})$, there is a significant difference between the averages of at least two of the groups. With reference to the multiple comparisons, this difference is between the faculty of science and letters and the faculty of fine arts.

In Table 11, Kruskal-Wallis $\mathrm{H}$ test was conducted to determine whether the frequency of sabotage behavior, which is one

Table 8: Kruskal-Wallis H Test Results of Displaying Frequencies of Abuse Behaviors of Participants Based on Faculty Variable

\begin{tabular}{lcccc}
\hline Groups & $\mathbf{N}$ & Rank average & $\mathbf{X}^{\mathbf{2}}$ & $\mathbf{p}$ \\
\hline Faculty of Education & 22 & 150.68 & 17.831 & $\mathbf{. 0 0 3}$ \\
Fac. Sci. and Let. & 40 & 103.34 & & \\
Fac. of Fina Arts & 16 & 75.63 & & \\
Engineering Fac.. & 50 & 104.21 & & \\
\hline
\end{tabular}


of the sub-dimensions of counter productive work behavior, varies according to the title variable. In Table 12, Kruskal-Wallis $H$ test was conducted to determine whether the frequency of theft behavior varies from the sub-dimensions of counter productive work behavior according to the title variable.

There was found a statistically significant difference between the displaying frequency of sabotage behaviors and the title variable $\left(X^{\mathbf{2}}=\mathbf{1 8 . 2 5 6}, \boldsymbol{p}<\mathbf{0 . 0 5}\right)$. In this circumstance, since the $p$-value is not bigger than 0.05 $(\boldsymbol{p}=\mathbf{0 . 0 0 1})$, there is a significant difference between the averages of at least two of the groups. With reference to the multiple comparisons, this difference is between professors and associate professor; between professor and assistant professor; between professor and research associate.

There was found a statistically significant difference between displaying the frequency of theft behaviors and the title variable $\left(\mathbf{X}^{\mathbf{2}}=\mathbf{1 1 . 7 8 0}, \boldsymbol{p}<\mathbf{0 . 0 5}\right)$. In this circumstance, since the $\mathrm{p}$-value is not bigger than 0.05 $(\boldsymbol{p}=\mathbf{0 . 0 1 9})$, there is a significant difference between the averages of at least two of the groups. With reference to the multiple comparisons, this difference is between the professor and associate professor.
Accordingly, $\mathrm{H}_{2}$ and $\mathrm{H}_{3}$ hypotheses were partly accepted.

\section{CONCLUSION AND DISCUSSION}

The most significant capital in terms of the organizations is the qualified workforce. Ignoring the 'human' factor may cause several problems such as absenteeism, job dissatisfaction, lack of improving the sense of belonging. Being satisfied the needs of the workers by the organization is the key point to maintain the organization membership. Several different factors that affect the organizational commitment create a difference in motivation of the workers. Following factors are important in developing the sense of belonging; constituting an effective communication network between workers and the organization; attitudes of managers toward their workers; managing the process together rather focusing on the job performance results; noticing daily life problems of workers within the process.

As academicians' organizational commitment level increases, there occurs a decrease in their abuse, theft and withdrawal

Table 9: Kruskal-Wallis H Test Results of Displaying Frequency of Production Deviance Behaviors of Participants based on Total Working Period in the Same Institution Variable

\begin{tabular}{lcccc}
\hline Groups & $\mathbf{N}$ & Rank average & $\mathbf{X}^{\mathbf{2}}$ & $\mathbf{p}$ \\
\hline Between 6-9 years & 28 & 126.89 & 11.522 & $\mathbf{. 0 0 9}$ \\
10 years and above & 105 & 105.07 & & \\
\hline
\end{tabular}

Table 10: Kruskal-Wallis H Test Results of Displaying Frequency of Sabotage Behaviors of Participants based on Faculty Variable

\begin{tabular}{lcccc}
\hline Groups & N & Rank average & $\mathbf{X}^{\mathbf{2}}$ & $\mathbf{p}$ \\
\hline Faculty of Edu. & 40 & 101.00 & 11.412 & $\mathbf{. 0 4 4}$ \\
Fac. of Fina Arts. & 16 & 121.19 & & \\
\hline
\end{tabular}


behaviors. Moreover, about the demographic profile of the academicians, the gender factor differentiates at continuance level. The academicians who have an administrative function display abuse behavior more than the academicians who have not. Senior academicians are more emotionally connected to their organizations. Academicians of Faculty of Science and Letters are more emotionally connected to their organizations in comparison with the academicians of the faculty of education. It is pointed out that the senior academicians display abuse behavior less. Academicians of the faculty of education display abuse behavior more than the academicians in the faculty of science and letters, faculty of fine arts and engineering faculty.

It is determined at the end of the analyses performed that gender, marital status and administrative function variables do not create a significant difference between counterproductive work behavior and its sub-dimensions. There are observed different observations in studies that survey whether displaying frequency of counter productive work behavior create a difference based on the gender variable. Kirbaşlar (2013) mentioned that the gender variable does not constitute a difference in counter productive work behavior. This situation shows parallelism with our research findings. However, Martinko et al., (2002), Kilıç (2013), Sezici (2015), Behrem (2017) revealed that males display counterproductive work behaviors more than females. With reference to Özüren (2017), females display counterproductive work behavior more than males. The reason for this situation can be explained by saying that the workers who work in different sectors develop different attitudes toward business. There are differences in studies that analyze the displaying frequency based on marital status. Kılıç (2013) pointed out that marital status variable does not create a significant difference in displaying frequency of counterproductive work behavior. This situation has parallelism with this research findings. However, according to Behrem (2017), workers who are single display counterproductive work behavior more than

Table 11. Kruskal-Wallis H Test results of Displaying Frequency of Sabotage Behavior Based on Title Variable

\begin{tabular}{lcccc}
\hline Groups & N & Rank average & $\mathbf{X}^{\mathbf{2}}$ & $\mathbf{p}$ \\
\hline Prof. Dr & 19 & 135.26 & 18.256 & $\mathbf{. 0 0 1}$ \\
Assoc. Prof. Dr & 29 & 101.00 & & \\
Assistant Prof. & 64 & 104.45 & & \\
Research Assistant & 96 & 111.35 & & \\
\hline
\end{tabular}

Table 12. Kruskal-Wallis H Test Results of Displaying Frequency of Theft Behaviors based on Title Variable

\begin{tabular}{lcccc}
\hline Groups & N & Rank average & $\mathbf{X}^{\mathbf{2}}$ & $\mathbf{p}$ \\
\hline Prof. Dr & 19 & 126.21 & 11.780 & $\mathbf{. 0 1 9}$ \\
Assoc. Prof. Dr & 29 & 103.00 & & \\
\hline
\end{tabular}


the workers who are married. The workers who are single have less responsibility in comparison with marries ones. This situation has a router effect on the attitudes of workers for their business. It is possible to say that workers are in the tendency to display counterproductive work behaviors by acting as lavish to organization assets.

It is determined at the end of the analyses that title, a total working period in career, a total working period in the same institution, and age variables do not constitute a significant difference on displaying frequency of counterproductive work behaviors. There are different surveys that research whether displaying frequency of counterproductive work behaviors create difference based on the seniority variable. Özüren (2017) mentioned that as the working period increases, displaying frequency of counterproductive work behaviors increases at the same time. Güldü (2014) revealed that as the working periods of workers increase, there occurs a decrease in displaying frequency of counterproductive work behaviors. Again, there are different findings in studies that research the displaying frequency of counterproductive work behaviors based on age variable. This situation shows parallelism with our research findings. Özüren (2017) and Güldü (2014) revealed that young generation workers display counterproductive work behaviors based on age variable.

This study was performed towards the academic staff study in a public university. For the next investigations, there should be conducted studies toward academic staff work in private university and public universities. Again, the same kind of investigations can be applied in administrative personnel besides the academic staff.
In this research, just the measuring instruments and data were collected. Using the measurement tools based on selfevaluation may cause emerging objective evaluation problems. Investigators can obtain more comprehensive results by using qualitative data.

\section{References}

Akbaş Tuna, A., \& Boylu Y. (2016). The Impacts Of Perceived Organizational Support And Job-Related Affective WellBeing On Counterproductive Work Behavior: A Study In Service Sector (in Turkish). İşletme Araştırmaları Dergisi, 8 (4), 505-521.

Allen, N.J., \& Meyer, J.P. (1991). A Three-Component Conceptualization of Organizational Commitment. Human Resource Management Review, 1(1), 61-89.

Anttila, E. (2014). Components Of Organizational: A Case Study Consisting Line Managers From Finnish Industrial Company (Master thesis), University of Tampere School of Education. Retrieved $\begin{array}{llll}\mathrm{f} & \mathrm{r} & \mathrm{m} & \mathrm{m}\end{array}$ https://trepo.tuni.fi/handle/10024/96724

Balay, R. (2014). Organizational Commitment in Administrators and Teachers (in Turkish ). Pegem Akademi. Ankara, Turkey.

Becker, H.S. (1960), Notes on The Concept of Commitment. The American Journal Of Sociology, 66 (1), 32-40.

Behrem, Ü. (2017). A Study on Investigation of the Effect of Five Factor Personality Traits on Anti-Productivity Behavior Through Organizational Justice Perception (Master thesis, in Turkish). Y1ldiz Teknik Üniversitesi, Sosyal Bilimler Enstitüsü, İstanbul, Turkey. 


\section{АНАЛИЗА ОДНОСА ИЗМЕЪУ ОРГАНИЗАЦИЈСКЕ ПОСВЕЋЕНОСТИ И КОНТРА-ПРОДУКТИВНОГ РАДНОГ ПОНАШАЊА МЕЪУ АКАДЕМИЦИМА}

Canan Baysal, Fulya Mısırdalı Yangil, Şerafettin Sevim

\section{Извод}

Ова студија истражује однос између контра-продуктивног радног понашања и организационе посвећености, што је један од проблема са којима се организације често сусрећу последњих година. Повезаност између афективне посвећености, нормативне посвећености и континуиране посвећености из димензија организационе посвећености и злоупотребе, одступања од производње, саботаже, крађе и повлачења из контрапродуктивног радног понашања, испитују се једно по једно. Студија је спроведена уз учешће 219 испитаника - академског особља, који раде на Универзитету Думлупнар. У студији се врши корелациона анализа да би се утврдио однос између променљивих. Поред тога, спроведени су "KruskalWallis H" и "Mann-Whitney U" тест како би се утврдила њихова повезаност са демографским варијаблама. Као резултат анализа, ово истраживање открива да димензије афективна посвећеност и нормативне посвећености, имају негативан правац и значајну везу са димензијама повлачења и злоупотребе. Поред тога, налази се негативан правац и значајна веза између континуиране посвећености и повлачења, злоупотребе, димензије отуђења.

Кључне речи: академско особље, контра продуктивно радно понашање, организациона посвећеност

Bennett, R.J. \& Robinson, S.L. (2000). Development of a Measure of Workplace Deviance. Journal of Applied Psychology, 85 (3), 349-360.

Çetin, F., \& F1kırkoca, A. (2010). Can Beyond Role Positive Behaviors be Predicted with Personal and Attitude Factors? (in Turkish), Ankara Üniversitesi SBF Dergisi, 65(4), 41-66.

Demirel, Y. (2009). Conceptual Approach to the Relationship Between Organizational Commitment and Anti-Productivity Behavior (in Turkish). İstanbul Ticaret Üniversitesi Sosyal Bilimler Dergisi, 8 (15), 115-132.

Doğan, A., \& Deniz, N. (2017). The Role of Organizational Culture in How the Perceived Leadership Style Affect the Emergence of Counterproductive Work
Behaviors (in Turkish). Uluslararas1 Sosyal Araştırmalar Dergisi, 10 (52), 1015-1024.

Doğruöz, E., \& Özdemir,M. (2018). AntiProduction Business Behaviors and Organizational Commitment Relationship in Educational Organizations (in Turkish), İlköğretim Online, 17 (1), 396-413.

Gerçek, M., (2017). Investigating the Effects Of Ethical Climate and Organizational Trust on Counterproductive Work Behaviors (in Turkish). Uluslararas 1 Sosyal Araştırmalar Dergisi, 10 (51), 953963.

Gül, H. (2003). The Behavioural Commitment Approach And Evaluation (in Turkish). Yönetim ve Ekonomi Dergisi, 10 (1), 73-83.

Güldü, Ö. (2014). The Effects of Life Satisfaction, Emotional Intelligence, and 
Moral Maturity on Counter Productive Work Behaviors in Female Workers (in Turkish). Kastamonu University Journal of Economics \& Administrative Sciences Faculty, 3 (2), 4864.

Hafidz, S.W.M. (2012). Individual Differences as Antecedents of Counterproductive Work Behaviour. Asian Social Science, 8 (3), 220-226.

Hollınger, R.C., \& Clark, J.P. (1983). Deterrence in the Workplace: Perceived Certainty, Perceived Severity, and Employee Theft. Social Forces, 62 (2), 398-418.

Kanten, P., \& Ülker, F. (2014). The Effect of Management Style on Counterproductive Behaviors: Mediating Role of Work Alienation (in Turkish). Sosyal Bilimler Enstitüsü Dergisi, 32, 16-40.

Kaya, N., \& Selçuk, S. (2007). How Does the Individual Success Drive Affect Organizational Commitment? (in Turkish). Doğuş Üniversitesi Dergisi, 8 (2), 175-190.

Kurbaşlar, M. (2013). A Study on the Investigation of Employees' Relationship with Ethical Climate Perceptions, Organizational Trust Perception and AntiProductivity Behavior (in Turkish). Yüksek Lisans Tezi, İstanbul Üniversitesi, Sosyal Bilimler Enstitüsü, İstanbul, Turkey.

Kılıç, S. (2013), The Relationship between Perceived Ethical Organizational Climate and Anti-Productivity Business Behavior (Doctoral dissertation, in Turkish). Niğde Üniversitesi, Sosyal Bilimler Enstitüsü, Niğde, Turkey.

Lunenburg, F.C. (2012). Compliance Theory and Organizational Effectiveness. International Journal of Scholarly Academic Intellectual Diversity, 14 (1), 1-4.

McMahon, B. (2007). Organizational commitment, relationship commitment and their association with attachment style and locus of control (Unpublished master dissertation). Master of Science in Psychology, Georgia Institute of Technology, Atlanta, USA.

Martinko, M.J., Gundlach, M.J., \& Douglas, S.C. (2002), Toward an Integrative Theory of Counterproductive Workplace Behavior: A Causal Reasoning Perspective. International Journal of selections and Assessment, 10 (1/2), 36-50.

Marcus, B., \& Schuler, H. (2004). Antecedents of Counterproductive Behavior At Work: A General Perspective. Journal of Applied Psychology, 89 (4), 6447-6660.

Meyer, J. P., Allen, N. J., \& Smith, C. A. (1993). Commitment to organizations and occupations: Extension and test of a threecomponent conceptualization. Journal of Applied Psychology, 78(4), 538-551.

Mount, M., Ilines, R., \& Johnson, E. (2006). Relationship of Personality Traits and Counterproductive Work Behaviors: The Mediating Effects of Job Satisfaction, Personnel Psychology, 59 (3), 591-622.

Noordin, F., Abdul Rahim, A.R., İbrahim, A.H., \& Omar, M.S. (2011). An Analysis of Career Stages on Organizational Commitment of Australian Managers. International Journal of Business and Social Science, 2 (17), 117-126.

Penney, L.M., \& Spector, P.E. (2002). Narcissism and Counterproductive Work Behavior: Do Bigger Egos Mean Bigger Problems?, International Journal of Selection and Assessment, 10 (1/2), 126-134.

Polatçı, S., Özçalık, F., \& Cindiloğlu, M. (2014). The Effects of Person Organizational Compliance on Anti-Productivity Business Behavior and Organizational Citizenship Behavior (in Turkish). Niğde Üniversitesi İktisadi ve İdari Bilimler Fakültesi Dergisi, 7 (3), 1-12.

Polatçı, S., \& Özçalık, F. (2015). The Mediating Role of Positive and Negative 
Affectivity on the Relationship Between Commitment (in Turkish). IV Örgütsel Perceived Organizational Justice and davranış kongresi.

Counterproductive Work Behavior (in Ulutürk, Ş. (2016). Organizational Turkish). Dokuz Eylül Üniversitesi Sosyal Culture and Organizational Commitment Bilimler Enstitüsü Dergisi, 17 (2), 215-234. Robinson, S.L., \& Bennett, R.J. (1995). A Typology of Deviant Workplace Behaviors: A Multıdımensional Scalıng Study. Academy of Management Journal, 38 (2), 555-572.

Sackett, P.R. (2002). The Structure of Counterproductive Work Behaviors: Dimensionality and Relationships with Facets of Job Performance. International Journal of Selection and Assessment, 10 (1\2), 5-11.

Sezici, E. (2015), The Role of Personality Tratts on Counterproductive Work Behaviors (in Turkish). Uluslararası İktisadi ve İdari İncelemeler Dergisi, 7(14), 1-22.

Spector, P. E. \& Fox, S. (2005). The stressor-emotion model of Counterproductive work behavior. S. Fox ve P. E. Spector, (Ed.), Counterproductive work behavior: Investigations of actors and targets içinde (151-174). Washington,

DC: APAAdded

Spector, P.E., Fox, S., Penney, L.M., Bruursema, K., Goh, A., \& Kessler, S. (2006). The Dimensionality of Counterproductivity: Are All Counterproductive Behaviors Created Equal?. Journal of Vocational Behavior, 68 (3), 446-460.

Özüren, Ü., (2017). Anti-Productivity Behaviors and Results Based on Nepotism Practices in Textile Enterprises (master thesis, in Turkish). İstanbul Kültür Üniversitesi, Sosyal Bilimler Enstitüsü, İstanbul, Turkey.

Tüfekçi, U., Yıldız Bağdoğan, S., \& Keser, A. (2016). Investigation of the Relationship Between Anti-Productivity Business Behaviors and Organizational 